\title{
Affinity Purification of Macrophage Migration Inhibitory Factor/Glycosylation Inhibiting Factor (MIF/GIF) from Bovine Brain by Using a Peptide Ligand Derived from a Novel Serpin
}

\author{
Masahiro Nishibori ${ }^{1}$, Naoki Nakaya ${ }^{1}$, Shuji Mori ${ }^{2}$, Masahiro Kawabata ${ }^{1}$, Akihito Tahara ${ }^{1}$ and Kiyomi Saeki ${ }^{1, *}$ \\ 'Department of Pharmacology, Okayama University Medical School, 2-5-1 Shikata-cho, Okayama 700, Japan \\ ${ }^{2}$ School of Health Sciences, Okayama University, 2-5-1 Shikata-cho, Okayama 700, Japan
}

Received March 4, 1996 Accepted May 7, 1996

\begin{abstract}
We purified macrophage migration inhibitory factor/glycosylation inhibiting factor (MIF/GIF) from bovine brain by using an affinity column with the C-terminal region peptide of a novel serpin as a ligand. The affinity purified preparation showing a single band on SDS-PAGE contained four peptides on RP-HPLC, which were converged into two peptides time-dependently. Sequence analysis and Western blotting revealed that one was identical to bovine MIF/GIF and the other was an N-terminally modified form of MIF/GIF. These results indicated that there exist at least two forms of MIF/GIF in the bovine brain and that they have an affinity for the C-terminal portion of the serpin.
\end{abstract}

Keywords: Macrophage migration inhibition factor/glycosylation inhibiting factor (MIF/GIF), Brain, Serpin

Macrophage migration inhibitory factor (MIF) was first characterized as a lymphokine produced by activated T-lymphocytes $(1,2)$. Functional expression cloning from activated human T-lymphocytes identified cDNA encoding a protein with MIF activity (3). Calandra et al. (4) demonstrated that MIF was also synthesized in the cells of monocyte/macrophage lineage and upon stimulation with bacterial lipopolysaccharide (LPS), tumor necrosis factor (TNF)- $\alpha$ and interferon- $\hat{\gamma}$, MIF was released from these cells. MIF in turn induced the release of TNF- $\alpha$ from macrophages through autocrine and paracrine mechanisms (3). Thus, MIF seems to be one of the critical cytokines in the host defense mechanism. Northern blot analysis showed that MIF was expressed in various tissues beyond the immune system (5-7), suggesting the widespread role of this cytokine. In fact, it was reported that MIF was released from the pituitary as a hormone after the injection of LPS into mice, contributing to the toxic response to endotoxemia $(8,9)$.

Recently, we purified a novel member of the serine proteinase inhibitor (serpin) family from the bovine brain (10). A serpin named B-43 from its molecular mass, was homologous to glia-derived nexin-1/protease nexin-1,

\footnotetext{
* To whom correspondence should be addressed.
}

plasminogen activator inhibitor-2, leukocyte elastase inhibitor and placental thrombin inhibitor, but had different biochemical properties from them. We synthesized a peptide corresponding to the C-terminal region of $\mathrm{B}-43$, which is a part of the peptide possibly cleaved from native serpin by target serine proteinases and contains the hydrophobic amino acid sequence suggested as a ligand for receptors of the serpin-serine proteinase complex and amyloid $\beta$-peptide (11). During the search for the putative target proteinase by using an affinity column with this synthetic peptide as a ligand, we found binding proteins to the peptide and identified them as cytokine MIF and its $\mathrm{N}$-terminally modified protein.

The fresh bovine brain was obtained from a slaughterhouse. The whole brain (about $400 \mathrm{~g}$ ) was homogenized with 1.21 of $20 \mathrm{mM}$ imidazole- $\mathrm{HCl}$ buffer, $\mathrm{pH} 7.2$, containing $1 \mathrm{mM}$ EDTA, $1 \mathrm{mM}$ EGTA and $1 \mathrm{mM}$ phenylmethylsulfonyl fluoride (buffer A) in a Waring blender. The homogenate was centrifuged at $25,000 \times \mathrm{g}$ for $50 \mathrm{~min}$. The resulting supernatant was applied to a peptide (LMVVPRFNANHPFLFFIQHSKT)-conjugated Affigel 10 (Bio-Rad, Richmond, CA, USA) column (8-ml bed volume) equilibrated with buffer $\mathrm{A}$. The column was successively washed with $300 \mathrm{ml}$ of buffer $A, 100 \mathrm{ml}$ of $1 \mathrm{M} \mathrm{NaCl}$ in buffer $\mathrm{A}, 60 \mathrm{ml}$ of $6 \mathrm{M}$ urea in buffer $\mathrm{A}$ and 
$60 \mathrm{ml}$ of $20 \mathrm{mM}$ sodium citrate buffer, $\mathrm{pH}$ 3.2. Finally, bound proteins were eluted with $6 \mathrm{M}$ urea in $20 \mathrm{mM}$ sodium citrate buffer, $\mathrm{pH} 3.2$ (fraction numbers 64-69 in Fig. 1A). The affinity purified proteins were applied to RP-HPLC (ODS-H $5 \mu \mathrm{m}, 4.6 \times 150 \mathrm{~mm}$; Chemcosorb, Osaka) and eluted with a linear gradient of acetonitrile in $0.1 \%$ trifluoroacetic acid (Fig. 1C). According to the retention time, we named the four peaks peptide 1 to peptide 4. Peptide 2 and peptide 4 were treated with endopeptidase (Lys-C; Boehringer Mannheim, Tokyo) or BrCN. The digest was applied to the HPLC column described above, and the collected peptides were analyzed by an automated protein sequencer (ABI 477A/120A;
Applied Biosystems, Foster City, CA, USA). HPLCpurified peptide $2(100 \mu \mathrm{g})$ in PBS was used for the immunization of rabbits (Seiwa Experimental Animals, Fukuoka). The protocol of immunization was described previously (12).

As shown in Fig. 1A, the proteins bound to a peptide (LMVVPRFNANHPFLFFIQHSKT)-conjugated affinity column were eluted with $6 \mathrm{M}$ urea at $\mathrm{pH} 7.2$ (fraction numbers 46-52 in Fig. 1A) and at pH 3.2 (fraction numbers 64-69 in Fig. 1A), after extensive washing with the equilibration buffer and $1 \mathrm{M} \mathrm{NaCl}$. The fractions eluted with $6 \mathrm{M}$ urea at $\mathrm{pH} 7.2$ contained several proteins on SDS-PAGE, while the latter fractions contained a single

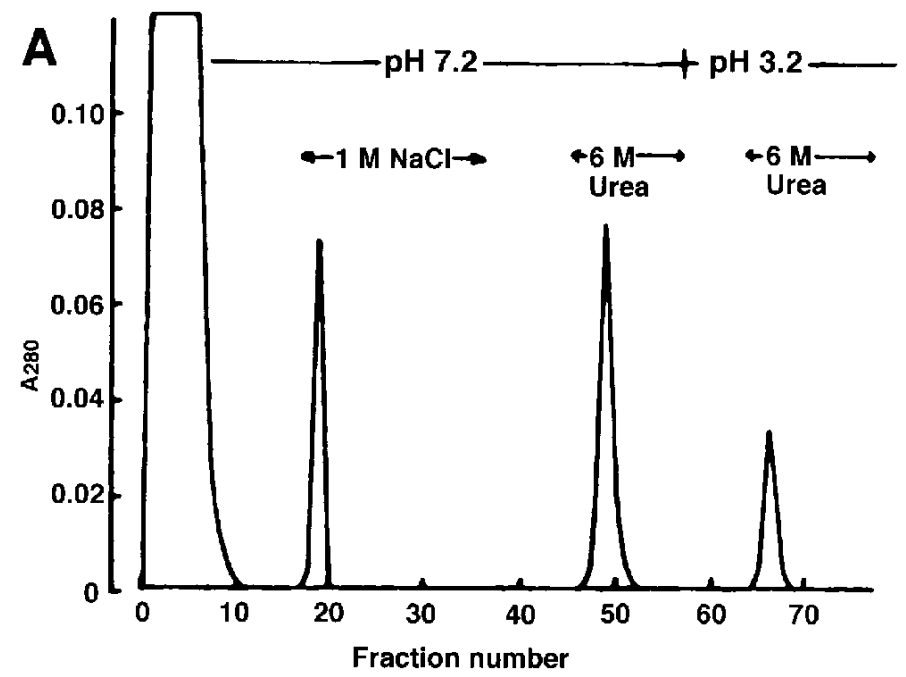

B
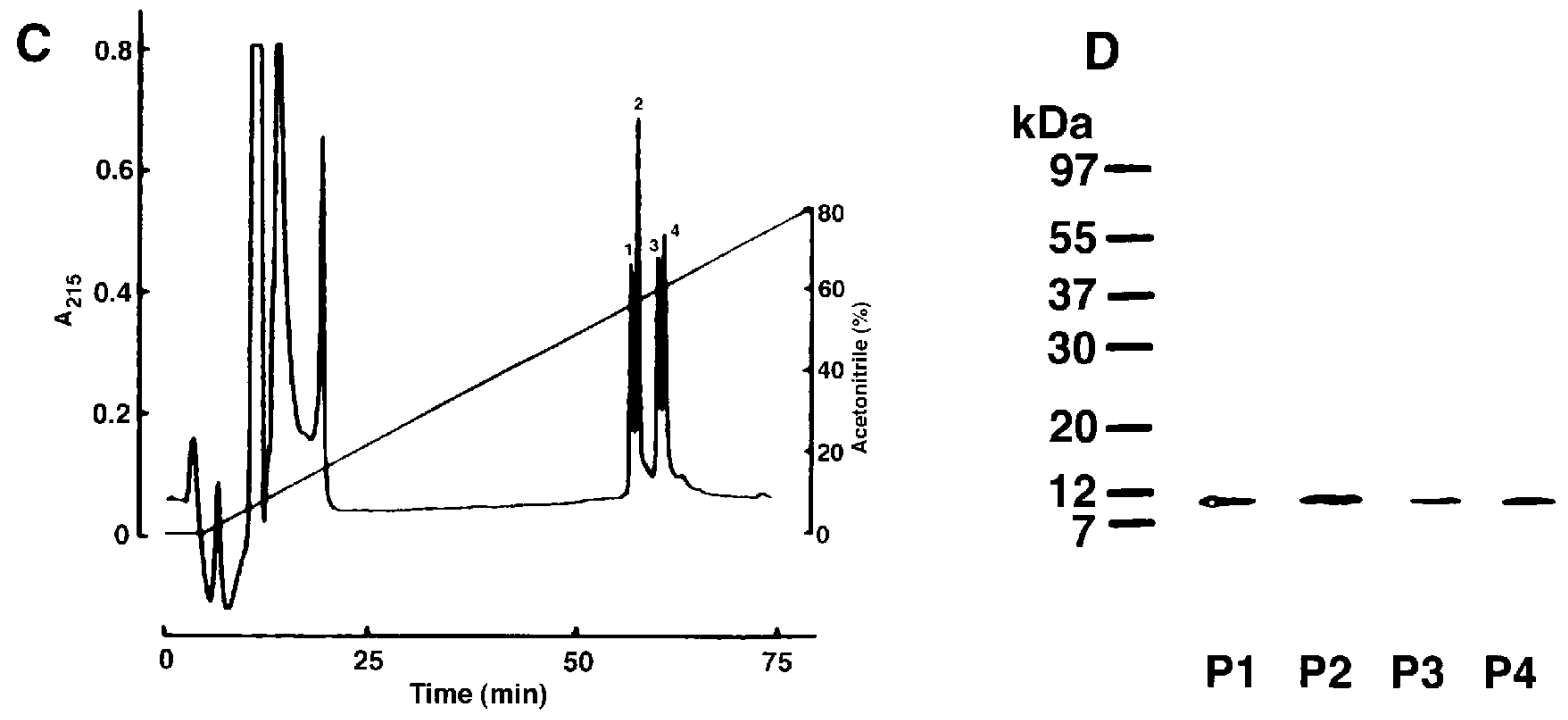

Fig. 1. Affinity purification of MIF/GIF proteins from bovine brain by using a peptide (LMVVPRFNANHPFLFFIQHSKT)conjugated Affigel 10 column. A: Column chromatography for the affinity purification of MIF/GIF. MIF/GIF was eluted with $6 \mathrm{M}$ urea in $20 \mathrm{mM}$ sodium citrate buffer, $\mathrm{pH} 3.2$ (fraction numbers 64-69). B: SDS-PAGE with Coomassie blue staining of the concentrate of fractions 64-69 in A. C: RP-HPLC separation of of the sample in B. D: Western blotting of four peptides (peptide 1 to peptide 4 in $C$ ) with anti-peptide 2 antiserum $(1: 2000)$. 


\begin{tabular}{|c|c|c|c|c|c|c|}
\hline & 10 & 20 & 30 & 40 & 50 & 60 \\
\hline Peptide 2 & PMF VVNTNVP & RASVPDGLLS & ELTQQLAQAT & GKPAQY I AVH & VVPDQLMTFG & GSSEPXALXS \\
\hline p $12^{\mathrm{a}}$ & PMFVVNTNVP & RASVPDGLLS & ELTQQLAOAT & GKPAQY I AVH & VVPDQLMTFG & GSSEPCALCS \\
\hline hMIF $^{\mathrm{b}}$ & MPMF I VNTNVP & RASVPDGFLS & ELTQOLAOAT & GKPPOY IAVH & VVPDQLMAFG & GSSEPCALCS \\
\hline hGIF ${ }^{c}$ & MPMF I VNTNVP & RASVPDGFLS & ELTOQLAQAT & GKPPOY IAVH & VVPDOLMAFG & GSSEPCALCS \\
\hline mMIF $^{\mathrm{d}}$ & MPMF I VNTNVP & RASVPEGFLS & ELTQOLAQAT & GKPAQY I AVH & VVPDQLMTFS & GTNDPCALCS \\
\hline \multirow[t]{2}{*}{ cMIF $^{\theta}$} & MPMF T I HTNVC & KDAVPDSLLG & ELTQQLAKAT & GKPAQY I AVH & IVPDOMMSFG & GSTDPCALCS \\
\hline & 70 & 80 & 90 & 100 & 110 & \\
\hline eptide 2 & LHS I GK I GGA & QNRSYSKLLX & GLLTERLR IS & PDR I Y INFXD & MNAANVGWNG & STFA \\
\hline 12 & LHS I GK I GGA & ONRSYSKLLC & GLLTERLR IS & PDRIYINFCD & MNAANVGWNG & STFA \\
\hline hMIF & LHS I GK I GGA & ONRSYSKLLC & GLLAERLR IS & PDRVY I NYYD & MNAASVGWNN & STFA \\
\hline hGIF & LHS I GK I GGA & ONRSYSKLLC & GLLAERLR IS & RDRVY INYYD & MNAANVGWNN & STFA \\
\hline mMIF & LHS I GK I GGA & ONRNYSKLLC & GLLSDRLHIS & PDRVYINYYD & MNAANVGWNG & STFA \\
\hline MIF & LYS I GK I GGQ & ONKTYTKLLC & DMI AKHLHVS & ADRVYINYFD & I NAANVGWNG & STFA \\
\hline
\end{tabular}

Fig. 2. Amino acid sequence of HPLC-purified peptide (Peptide 2) and a comparison with MIF/GIF from different species. "Reported by Galat et al. (13). "Deduced from the human MIF (hMIF) cDNA sequence (3). 'Deduced from the human GIF (hGIF) cDNA sequence (14). ${ }^{\mathrm{d} D e d u c e d}$ from the murine MIF (mMIF) cDNA sequence (7). 'Deduced from the chicken MIF (cMIF) cDNA sequence (7).

band on SDS-PAGE (Fig. 1B). The apparent molecular mass of the protein eluted at $\mathrm{pH} 3.2$ was about $10 \mathrm{kDa}$ under reducing and nonreducing conditions. The 10-kDa band was separable into four peaks (peptide 1 to peptide 4) on RP-HPLC eluted with a linear gradient of acetonitrile (Fig. 1C); and the four peptides were converged into two peaks, peptide 2 and peptide 4 , within one week after the purification at $4^{\circ} \mathrm{C}$. The complete protein sequencing of peptide 2 and the homology search showed that peptide 2 was identical to bovine brain MIF/glycosylation inhibition factor (GIF) protein (13) and was highly homologous to MIF/GIF from other species $(3,7,14)$ (Fig. 2). The blank position of signals in peptide 2 corresponds to the cysteine residue in MIF/GIF from different sources. GIF was reported to suppress the synthesis of IgE through the inhibition of glycosylation of IgE binding protein (14). Peptide 1 had the same $\mathrm{N}$-terminal amino acid sequence as peptide 2 ( Pro $^{1} \cdots$ Ala $^{27}$ ). Peptides 3 and 4 were $\mathrm{N}$-terminally blocked. The partial amino acid sequence of peptide 4 after the cleavage by Lys-C endopeptidase indicated that peptide 4 had the same sequence as peptide $2\left(\mathrm{Pro}^{33} \cdots \mathrm{Iso}^{64}\right)$. Anti-peptide 2 antiserum recognized four peptides on Western blotting (Fig. 1D). These results as a whole indicated that the affinity purified proteins were MIF/GIF, and its N-terminally modified form and that either of them had conformational variants.

Galat et al. $(13,15)$ purified two species of MIF/GIF molecule having different isoelectric points, 9.4 and 9.5 , by using chromatofocusing and ion exchange chromatographies. Since both species with different pI values were not N-terminally blocked, they may correspond to peptide 1 and peptide 2 in the present study.

The peptide used as a ligand for the affinity column is derived from the sequence of a novel serpin (B-43) purified from bovine brain and corresponds to a part of the peptide sequence released from native $\mathrm{B}-43$ by putative proteinases (10). The interaction between the serpinderived peptide and MIF/GIF proteins must be strong and specific because the bound proteins were only eluted after extensive washing with $1 \mathrm{M} \mathrm{NaCl}$ and $6 \mathrm{M}$ urea at pH 7.2 and because there was no protein recovered when we used an Affigel 10 column without ligand. Recently we observed that B-43 formed an SDS-stable complex with thrombin (unpublished observation), strongly suggesting that B-43 was an inhibitor of thrombin present in the brain. Therefore, it is very important to examine whether MIF/GIF has any influence on the formation of the complex between B-43 and the proteinase.

Lanahan et al. (5) and Paralkar and Wistow (6) demonstrated the high expression of MIF mRNA in the brain among the tissues examined. It has been reported that MIF is a hormonal factor released from the anterior pituitary after the challenge with LPS, exacerbating endotoxemia $(8,9)$; However, little is known about the role of MIF/GIF in the brain except for the pituitary. As a serine proteinase and the serpin system has been suggested to be involved in neuronal degeneration, repair and plasticity, the interaction between MIF/GIF and a peptide derived from B-43 may play a role in this context. Identification of the binding peptide to MIF/GIF will promote the studies on this cytokine in the brain. B-43 was demonstrated to be present in pyramidal cells of the bovine cerebral cortex and glial fibrillary acidic protein positive astrocytes in the white matter of the cerebrum (12). The cellular localization of MIF/GIF in the brain should be clarified. 


\section{Acknowledgments}

We gratefully acknowledge Shizuko Yokoyama for her excellent technical assistance. This work was partly supported by Grant-inAid No.06670114 from the Japanese Ministry of Education, Science, Sports and Culture, Japan and a Grant from Ryobiteien Memorial Foundation, Japan.

\section{REFERENCES}

1 Bloom BR and Bennet B: Mechanism of a reaction in vitro associated with delayed-type hypersensitivity. Science $153,80-82$ (1966)

2 David JR: Delayed hypersensitivity in vitro: Its mediation by cell free substances formed by lymphoid cell-antigen interaction. Proc Natl Acad Sci USA 56, 72- 77 (1966)

3 Weiser WY, Temple PA, Witek-Giannoti JS, Remold HG, Clark SC and David JR: Molecular cloning of a cDNA encoding a human macrophage migration inhibitory factor. Proc Natl Acad Sci USA 86, 7522-7526 (1989)

4 Calandra T, Bernhagen J, Mitchell RA and Bucala R: The macrophage is an important and previously unrecognized source of macrophage migration inhibitory factor. J Exp Med 179, 1895- 1902 (1994)

5 Lanahan A, Williams JB, Sanders LK and Nathans D: Growth factor-induced delayed early response genes. Mol Cell Biol 12, 3919 - 3929 (1992)

6 Paralkar V and Wistow G: Cloning the human gene for macrophage migration inhibitory factor (MIF). Genomics 19, 48-51 (1994)

7 Wistow GJ, Shaughnessy MP, Lee DC, Hodin J and Zelenka PS: A migration inhibitory factor is expressed in the differentiating cells of the eye lens. Proc Natl Acad Sci USA 90, $1272-1275$ (1993)
8 Bernhagen J, Calandra T, Mitchell RA, Martin SB, Tracey KJ, Voelter W, Manogue KR, Cerami A and Bucala R: MIF is a pituitary-derived cytokine that potentiates lethal endotoxaemia. Nature 365, 756-759 (1993)

9 Bucala R: Identification of MIF as a new pituitary hormone and macrophage cytokine and its role in endotoxic shock. Immunol Lett 43, 23-26 (1994)

10 Nishibori M, Chikai T, Kawabata $M$, Ohta J, Ubuka $T$ and Saeki K: Purification of novel serpin-like protein from bovine brain. Neurosci Res 24, 47-52 (1995)

11 Joslin G, Fallon RJ, Bullock J, Adams SP and Perlmutter DH: The sec receptor recognizes a pentapeptide neodomain of $\alpha_{1}$ antitrypsin-protease complexes. J Biol Chem 266, 11282-11288 (1991)

12 Nishibori M, Ohtsuka A, Kawabata M, Nakaya N, Murakami $\mathrm{T}$ and Saeki K: A novel serpin-like protein, B-43, exists in both neurons and astrocytes: an immunohistochemical study in the parietal region of the bovine brain. Neurosci Lett 200, 125-128 (1995)

13 Galat A, Riviere S, Bouet $\mathrm{F}$ and Menez A: A diversified family of $12-\mathrm{kDa}$ proteins with a high amino acid sequence similarity to macrophage migration-inhibitory factor (MIF). Eur $\mathrm{J}$ Biochem 224, 417-421 (1994)

14 Mikayama T, Nakano T, Gomi H, Nakagawa Y, Liu Y, Sato M, Iwamatsu A, Ishii Y, Weiser WY and Ishizaka K: Molecular cloning and functional expression of a cDNA encoding glycosylation-inhibiting factor. J Immunol 90, 10056-10060 (1993)

15 Galat A, Riviere S and Bouet F: Purification of macrophage inhibitory factor (MIF) from bovine brain cytosol. FEBS Lett 319, 233-236 (1993) 